\title{
Chemistry and Power in Recent American Fiction
}

\author{
Philip Ball
}

\begin{abstract}
Writers of fiction have always held up a mirror to the world around them. The perspective they typically present is not one gathered from polls of public opinion, nor is it culled from the way issues are presented in the media. Yet in retrospect, the personal attitudes and views expressed in good literary fiction frequently prove to offer a revealing snapshot of trends in thought and topics of debate in the writer's milieu. With this in mind, I shall explore some of the themes on chemistry and society developed in the fictional works of three modern American writers. I believe that these examples provide food for thought, and possibly a little encouragement, to those who despair at the tarnished image that chemistry commonly seems to have in broader public discourse today. For while all of the texts I consider examine some of the fears often expressed about the chemical industry, they show a willingness to engage with issues of risk (real and perceived), social benefits, changing patterns of consumer behavior, and responsibility that is not always present in more conventional modes of ecocriticism.
\end{abstract}

Keywords: chemistry in literature, chemistry in society, science and art, fiction.

\section{Introduction}

What strikes one first about chemistry in twentieth-century literature is that, in comparison to physics, biology and mathematics, there is so little of it. I do not think it is hard to understand why this is so. Chemistry is largely absent from our contemporary literature for the same reason that it is largely absent from any public discussion and dissemination of science, whether that be in popular science writing, television programs, or cultural debates. Fiction writers have always, by and large, sought to explore big themes: that is surely as true of Cervantes, Swift, Hugo, and Dostoevsky as it is of Martin Amis, Margaret Atwood or Kazuo Ishiguro, to pick out just three contemporary writers who have drawn on ideas from science. Physics and biology appear to explore the major questions that a work of fiction might also explore: 
What does it mean to be human? What is the nature of existence? Amis used the post-Einsteinian plastic notion of time to run the Holocaust in reverse in his book Time's Arrow (1992), while both Atwood (Oryx and Crake, 2003) and Ishiguro (Never Let Me Go, 2005) project genetic engineering into a dystopian future.

Chemistry, in contrast, seems to have little to offer in the way of grand themes. In fact, it often seems today not to be asking any questions about the world at all: it is primarily a synthetic science, a science bound up with making things. Even many scientists, if they have no real knowledge of chemistry, seem unable to find a way to fit this discipline into their vision of what science is about, namely the process of discovering how the world works. Most current distinctions that are drawn between science and technology will place today's chemistry squarely within the realm of technology, or at least applied science, concerned as it is much more with invention than with discovery.

That was not always so. When far less was known about the material constitution of the world and the nature of its elemental building blocks, chemistry became temporarily a 'discovery science' par excellence. This was why, when chemists were trying to understand what made elements join in some combinations but not others - to understand what they called the notion of affinity - Wolfgang von Goethe famously found in chemistry an appropriate metaphor for the study of human relationships in his novel Elective Affinities (1809).

Now things are different. The 'big questions' of chemistry - what the elements are and how they unite in the material world - have been more or less answered. Today the vast majority of publications in the chemical literature are concerned with synthesis (Schummer 2004), which can look like, and indeed is sometimes practiced as, more of a craft than a science.

That is not, however, an a priori reason why it should lack appeal to modern writers. To say that chemistry is neglected in fiction because it poses no big questions is not to offer a necessary truth; rather, it is to say that we live in a particular kind of intellectual climate. It is a climate that we have inherited from antiquity, one in which the abstract and theoretical are valued above the manual and practical. Classical Greek philosophers were often careful observers of nature, but they rarely engaged in experiment, and even then it would not be to learn about the world but merely to demonstrate the validity of their ideas. It was only when this philosophical strand mingled with the practical skills of the Middle East in Hellenistic Alexandria that the great experimental Greek scientists such as Archimedes and Hero appeared (Multhauf 1993). That blend, of course, gave rise to the proto-science of alchemy; but alchemy, as well as practical chemical arts such as dyeing, pottery, metallurgy, cooking, and brewing, was never deemed a subject worthy of scholarly study at the medieval universities, where astronomy, geometry, and music 
were the pre-eminent 'sciences'. Although medicine was taught academically, the doctors typically never laid a finger on a human body - manual medical operations such as cautery, bone-setting, and blood-letting were left for lowly surgeons to perform.

Yet chemistry could have become a rich source of inspiration and metaphor for everyone interested in the puzzles and dilemmas of human existence. In the chemical philosophies that flourished in the sixteenth and early seventeenth centuries, it was precisely that: these theories, now seemingly so arcane and indeed occult, can be considered the first proto-scientific 'theories of everything'. This aspect of Renaissance science, which drew in particular on the ideas of the Swiss alchemist and physician Paracelsus and left its mark on the notion of science developed by Francis Bacon, has been discussed by the American historian of science Allen Debus (1978). It came sometimes into explicit conflict with the mechanistic view of science initiated by René Descartes and his followers, and which of course ultimately triumphed in the form of the deterministic mechanics of Isaac Newton.

I am not saying that this was a mistake, and that we should instead have chosen to embrace Paracelsian chemical philosophy, which typically veered towards a rather nebulous mysticism. I am simply pointing out that these developments in science were not independent of our culture as a whole, and that they continue to shape it.

\section{Levi's legacy}

The British biologist Peter Medawar, one of the most perceptive commentators on the practice of science in the mid-twentieth century, has expressed very cogently where this preference for the abstract over the practical has led us:

Francis Bacon was not the first to distinguish basic from applied science, but no one before him put the matter so clearly and insistently, and the distinction as he draws it is unquestionably just [...] Bacon's distinction is between research that increases our power over nature and research that increases our understanding of nature [...] Unhappily, Bacon's distinction is not the one we now make when we differentiate between the basic and applied sciences. The notion of purity has somehow been superimposed upon it, and in a new usage that connotes a conscious and inexplicably self-righteous disengagement from the pressures of necessity and use. The distinction is not now between the empirically founded sciences and those whose axioms were supposedly known a priori; rather it is between polite and rude learning, between the laudably useless and the vulgarly applied, the free and the intellectually compromised, the poetic and the mundane.[Medawar 1984] 
Understandably, writers of fiction want the poetic, not the mundane. That is to say, they have been led, like our culture as a whole, to expect to find the poetic in the so-called pure sciences, the sciences of 'how the world works': in physics and biology. It has required a genuine insider, someone who knew chemistry intimately, to show that in fact there is plenty of poetry in chemistry too. That person was, of course, the Italian chemist and writer Primo Levi.

Inevitably one must mention Primo Levi in the context of this article's topic. But I confess that I intend to say rather little about him, since I rather feel that to dwell on Levi would be to cheat on my aim here. He had a privileged perspective in that he was a chemist, whereas I want to look at how chemistry has impacted on writers who did not have that training, or indeed that specific focus in their oeuvre. But I do wish to point out that Levi's classic book The Periodic Table (published in Italian in 1975) grasps the essence of chemistry's allegories in a manner that is very much akin to the chemical philosophies of centuries earlier, where the transformations that are conducted in the chemical laboratory are perceived as reflecting the processes of human life. In Paracelsian chemical philosophy these correspondences were seen as much more than a metaphor; but I think it is fair to say that they were rather more than metaphors for Levi too, who was clearly moved by a profound empathy for chemical science. He writes, for example, with something like reverence about the process of distillation:

Distillation is beautiful. First of all, because it is a slow, philosophic, and silent occupation, which keeps you busy but gives you time to think of other things, somewhat like riding a bike. Then, because it involves a metamorphosis from liquid to vapour (invisible), and from this once again to liquid; but in this double journey, up and down, purity is attained, an ambiguous and fascinating condition, which starts with chemistry and goes very far. And finally, when you set about distilling, you acquire the consciousness of repeating a ritual consecrated by the centuries. [Levi 1985]

Levi also found ways to expound the synthetic nature of chemistry, the fact that it was about making things. In his novel The Monkey's Wrench (1978) he points out that chemistry has in fact much in common with the profession of the engineer. The narrator, talking to a construction worker named Faussone who assembles bridges, says

The profession I studied in school and that has kept me alive so far is the profession of a chemist. I don't know if you have a clear idea of it, but it's a bit like yours; only we rig and dismantle very tiny constructions [...] I've always been a rigger-chemist, one of those who make syntheses, who build structures to order, in other words.

And he goes on to explain what that entails - how difficult it is to assemble a structure using atoms: 
[...] when you come down to it, we're bad riggers. We really are like elephants who have been given a closed box containing all the pieces of a watch: we are very strong and patient, and we shake the box in every direction and with all our strength. Maybe we even warm it up, because heating is another form of shaking. Well, sometimes, if the watch isn't too complicated, if we keep on shaking, we succeed in getting it together; but, as you can imagine, it's more reasonable to proceed a bit at a time, first attaching two pieces, then adding a third, and so on. It takes more patience, but actually you get there first. And most of the time that's the way we do it. [Levi 1987]

Chemistry has been fantastically lucky to have Levi's advocacy - not so much because he is a chemist who can write beautifully (that is simply the recipe for a good science writer) but because he is first and foremost an artist who, to our good fortune, happened to take up the profession of chemistry.

\section{Home truths about chemistry}

But Levi's almost spiritual response to chemistry is unusual now. The writers on whom I want to focus here are distinguished in having understood that, rather than standing remote from the realities of human existence, chemistry has become central to it. Their interest in chemistry is materialistic, for the simple and obvious, although generally overlooked, reason that our lives are materialistic. Increasingly, we live in a synthetic environment, a world of new and unfamiliar materials, in which our foods and clothes and medicines are manufactured in factories and laboratories. I am aware that this is a perspective usually voiced as a criticism, a lament about a world in which 'artificial' and 'synthetic' are terms of derogation, to be contrasted with the goodness that inheres in 'natural' things. But it was not always so. For Francis Bacon, synthesis and artifice were the primary aims of science, and his scientific agenda, which imposed a strong influence on the founders of the Royal Society in London, was pre-eminently a practical one. Scientists, he said, should be like bees. "The bee", he wrote,

extracts matter from the flowers of the garden and the field, but works and fashions it by its own efforts. The true labour of philosophy resembles hers, for it neither relies entirely nor principally on the powers of the mind, nor yet lays up in the memory the matter afforded by the experiments of natural history and mechanics in its raw state, but changes and works it in the understanding. [Bacon 1620, p. 349]

The three writers I wish to discuss here - Don DeLillo, Richard Powers, and Thomas Pynchon - do not exactly celebrate artifice in the way that Bacon does, but neither, I think, do they present a simple-minded critique of it. I 
am unapologetic about the fact that they are all American writers, because I think that is no coincidence: few national cultures have embraced the synthetic to the extent that America has, and DeLillo and Powers in particular phrase their analysis of what we might call 'everyday chemistry' with a seemingly conscious cultural specificity. Moreover, these three authors are commonly bracketed together - Powers, for instance, has been described as "one of the few younger American writers who stake a claim to the legacy of Pynchon and DeLillo", while DeLillo in turn has been said to share the "mad willfulness' of Pynchon - and I feel that part of the reason for this is the way that they are able to engage in an informed way with the immediacy of our chemical and material world.

DeLillo's take on this issue is illustrated most clearly in his 1984 novel White Noise. This, the eighth of his novels, is widely regarded as his 'breakthrough' work, an accessible and highly entertaining satire on the fears and myths of contemporary American life. It exemplifies what critic Charles Molesworth has identified as DeLillo's recurrent themes:

No other contemporary novelist could be said to outstrip DeLillo in his ability to depict that larger social environment we blandly call everyday life. Brand names, current events, fads, the society of the spectacle, and the rampant consumerism that has become our most noticeable, if not our most important, contribution to history, all are plentifully and accurately recorded throughout

DeLillo's work. [Molesworth 1991]

Yet White Noise divided critics and reviewers. Some saw it as a straightforward critique of the American way of life: a 'liberal' attitude that infuriated conservative commentators. For others, it was almost a celebration of that same post-modern perspective, in which high art is mixed with consumer culture and the philosophy of Nietzsche is no more or less valid than the philosophy of the breakfast-cereal packet. "DeLillo has been read both as a denouncer and as a defender of post-modern culture", says Mark Osteen (2000), who feels that neither interpretation really fits White Noise.

From the very first paragraph, which describes the return of students to college after the summer vacation, DeLillo makes it clear that he is preoccupied with the material and specifically the synthetic aspects that pass unquestioned in modern American life:

As cars slowed to a crawl and stopped, students sprang out and raced to the rear doors to begin removing the objects inside; the stereo sets, radios, personal computers; small refrigerators and table ranges; the cartons of phonograph records and cassettes; the hairdryers and styling irons; the tennis rackets, soccer balls, hockey and lacrosse sticks, bows and arrows; the controlled substances, the birth control pills and devices; the junk food still in shopping bags - onion-and-garlic chips, nacho thins, peanut crème patties, Waffelos and 
Kabooms, fruit chews and toffee popcorn; the Dum-Dum pops, the Mystic mints. [DeLillo 1984, p. 3]

This, DeLillo implies, is the complete kit you need for modern life in America, all of it essential, including - perhaps especially - those brand-named items that remain an utter mystery to non-Americans: the Waffelos and Kabooms. The book is a fantastical grotesque, Rabelais transferred to the late twentieth century - for it was Rabelais who introduced such absurd, comical lists into the novel (Rabelais 1532, 1534). And he too wrote satire with serious intent.

DeLillo's narrator, Jack Gladney, teaches at the College-on-the-Hill in a town called Blacksmith, where he is chairman of the department of Hitler studies, a discipline he invented in 1968. Jack has subsequently been concealing the fact that he actually does not know the German language, while making ineffectual and clandestine attempts to learn it. Thus Jack's professional life is every bit as superficial and synthetic as his material life, a world of strange and unfamiliar substances which he and his family wear and use and ingest without question. "We began quietly plastering mustard and mayonnaise on our brightly colored food", he says. They sense something is not right about this, but the culture in which they are embedded renders them powerless. "This isn't the lunch I'd planned for myself”, Jack's wife says. "I was seriously thinking yoghurt and wheat germ."

This is a life that is pharmaceutically sustained. Everyone is on medication. When Jack's daughter asks him “What do you take?", he tells her, "Blood pressure pills, stress pills, allergy pills, eye drops, aspirin. Run of the mill." But some medication is not described by function; it simply has a medical-sounding name. Jack's wife is on a drug called Dylar, and he can discover nothing about what it is supposed to do. All he knows (at first) is that it makes her absent-minded.

Jack Gladney's world is full of these trade names for synthetic chemicals and materials, and they serve the dual purpose of comforting and alienating. People recite the names because that is all they have by way of understanding or describing these substances: a meaningless, superficial, invented label. If you use the label, it sounds as though you have taken command of the substance, it makes it something familiar and casually appropriated - even though you have absolutely no idea what it is. Jack starts to see or hear about teams of men in protective clothing who appear around Blacksmith, and in every case he specifies that the garments are made from Mylex, although it is clear that this means nothing to him. 'Mylex' sounds technical, it sounds as though he knows what he is talking about, although there is (so far as I know) no such substance. There is a knowing, post-modern irony at work here. It is widely recognized that the sloppy fictional mode particularly prevalent in movie scripts tends to employ scientific words without any no- 
tion of what they mean, simply to add a patina of apparent scientific credibility (if not merely to signpost supposedly scientific content). DeLillo has Jack Gladney do the same thing, and now the author is not inadvertently showing his ignorance but pointing out how this tendency has become a stock aspect of modern life.

But there is no doubt that Jack's identification of the protective material as Mylex has another implication. If he had simply said 'plastic', the effect would not be the same. Mylex has a corporate aura - it suggests that the men in protective clothing are part of an operation as inscrutable as the fabrics they wear, an organization shrouded in the mysterious trappings of power. And as the tale proceeds, this operation becomes more ominous. The Mylex men are clearly involved in some kind of clean-up procedure, and eventually this literally spills out into the open when a train carrying some chemical agent is derailed, creating a fire or explosion that sends a cloud of toxic material to threaten Blacksmith. When Jack tries to establish the nature of the spill, he is faced with a similar blank, forbidding label: his son Heinrich tells him that "It's called Nyodene Derivative or Nyodene D." When Jack finally sees this so-called 'airborne toxic event', again he seeks refuge in names that he has heard but not understood: "It was a terrible thing to see, so close, so low, packed with chlorides, benzines [sic], phenols, hydrocarbons, or whatever the precise toxic content."

Nyodene, Mylex, Dylar: clearly names from the same stable as Nylon, Kevlar, Mylar, the ubiquitous synthetic products of the chemical industry, presented to us without explanation or justification. At one point, DeLillo simply lists them, à propos of nothing in particular: "Dacron, Orlon, Lycra Spandex", one of his recurring little mantras to the modern world. He calls such labels "supranational names, computer-generated, more or less universally pronounceable. Part of every child's brain noise, the substatic regions too deep to probe."

It might be tempting to read all of this as standard knee-jerk paranoia in response to our 'chemical world', a reiteration of the popular notion that all 'chemicals' are bad and the chemical industry is inevitably polluting. Some critics have indeed interpreted White Noise as, in part, a cautionary fable about such ecological and toxicological human-made hazards. Perhaps that was not surprising in view of the context in which it was first published in January 1985 - just a month after the leakage of methyl isocyanate gas from Union Carbide's chemicals plant at Bhopal in central India, which claimed thousands of lives. Tom LeClair argues that the toxic substances in the airborne toxic event "were engineered to kill and thus give man control over the Earth; instead, they threaten their inventors and nature". White Noise, he says, is an expression of DeLillo's "rage at and pity for what humankind does to itself" (LeClair 2003). 
But I think DeLillo's fable is more subtle than that. Jack does not regard the toxic cloud as the inevitable product of humankind's hubris in making these awful substances; rather, he is perplexed at how the prosaic process of synthesis and artifice can generate something that resembles a natural hazard:

This was death made in the laboratory, defined and measurable, but we thought of it at the time in a simple and primitive way, as some seasonal perversity of the earth like a flood or tornado, something not subject to control. Our helplessness did not seem compatible with the idea of a man-made event.

[DeLillo 1984, p. 127f.]

The synthetic chemicals that pervade Jack's life are regarded by him as benign, or at least as necessary. He is bewildered when they seem to turn on him. Yet he experiences no conversion to any sort of back-to-basics environmentalism in the book, despite acquiring a potentially fatal condition from the toxic airborne event and despite discovering unwholesome truths about his wife's Dylar, a drug created to suppress overwhelming fears of mortality.

Indeed, there is a good case to be made that White Noise is a discourse on the irrational and obsessive fear of death in modern middle-class America, and that the airborne toxic event is just a symbol of that. When Jack finally sees the deadly cloud, it is described in mythological terms: "The enormous dark mass moved like some death ship in a Norse legend, escorted across the night by armoured creatures with spiral wings." Its appearance spawns folk tales among the awed inhabitants of Blacksmith: it "had released a spirit of imagination. People spun tales, others listened spellbound".

This, I think, brings us to the crux of White Noise. Its true subject seems, above all else, to be the mythology that underlies suburban American life: the way that feelings of disempowerment and helplessness engendered by a dependence on commodities and services provided by faceless corporations and invisible forces create their own superstitions, belief systems, and legends. "The genius of the primitive mind", Jack acknowledges, "is that it can render human helplessness in noble and beautiful ways." According to critic Mark Conroy (2003), "If anything, the scientific advance chiefly on display in this world $[\ldots]$ reduces the people further to infantilism, primitive fantasy, and dependence upon the system as if upon a deity $[\ldots]$ the products of modern technology become themselves fetish objects".

This theme is made explicit through the character of Murray Jay Siskind, an ex-sportswriter and now a colleague of Jack's at the College-on-the-Hill who wants to explore the mythology and mystique of Elvis in the same way that Jack does with Hitler. Siskind studies packaging in the supermarket and scans the advertisements in trashy magazines like Ufologist Today. "I want", he says, apparently voicing DeLillo's intentions, "to immerse myself in American magic and dread." 
Within this pantheon of contemporary occult forces, technology, like the old gods, holds both the threat of damnation and the promise of salvation. "Give yourself up to it", Siskind urges Jack. "Believe in it." Jack himself recognizes that these forces are at play, and that our response to them is primeval. "The greater the scientific advance", he tells his wife, "the more primitive the fear." But these primitive fears are now mediated through brand names, advertising, television. The recurring triads of names are a part of Siskind's 'American magic': they are like incantations, with echoes of a recitation of the Holy Trinity that are not simply ironic. Fetish objects, indeed. Even the airborne toxic event is presented in this way: the authorities seize on various euphemisms for it before alighting on this one, seeking the right balance of gravity and distance. Dealing with the crisis becomes a question of finding the right slogan. The deadly cloud, Jack notes, is presented to them in consumerist terms, like an advertising campaign for death. "White Noise", says critic Michael Valdez Moses,

is DeLillo's exploration of an America in which technology has become not merely a pervasive and mortal threat to each of its citizens, but also, and more importantly, a deeply ingrained mode of existing and way of thinking that is the characteristic feature of the republic. [Moses 1991]

Where, we might reasonably ask, does DeLillo himself stand in all of this? That it is hard to answer that question contributes to the book's richness. As Thomas DiPietro writes,

In DeLillo's truly Swiftean satire, we're never sure what he himself believes or what he thinks of his characters. As in Swift, we're instead forced to rely on ourselves, to measure literary experience against our own sense of reality. [Lentricchia 1991]

This refusal to provide a neat message, this offering of a range of perspectives, some of them only half-glimpsed, is a characteristic of much postmodern fiction, and certainly it can be found in the other two books I discuss below. However, Ursula Heise offers one particularly intriguing interpretation of DeLillo's stance that has a special resonance from the point of view of the book's attitudes to technology in general and to chemical technology in particular. She suggests that DeLillo has found a way to explore the complex and in some sense irresolvable issues of risk with which modern life confronts us. "In White Noise", Heise (2002) says, "DeLillo is concerned with the way in which new kinds of risk have invaded the lives of even those citizens that might earlier have had reason to believe themselves safe from their most dire consequences." We are bombarded daily with health scares, and not just from synthetic chemicals with obscure, futuristic names but from the ingredients in familiar foods and drinks that we never even knew were there. One day red wine is good for you; the next, it is a hazard. Beware sugar; be- 
ware salt. These oils are good; those are bad. New pollutants are being detected as fast as new methods are devised to detect them (and, of course, because of those very innovations). Old drugs prove to have unforeseen side effects; can we trust the new alternatives any better?

Jack Gladney's family is surrounded by such vague and incomprehensible dangers, of which the airborne toxic event is just the most concrete example. His son Heinrich's hairline is receding, although he is just fourteen. "Did his mother consume some kind of gene-piercing substance when she was pregnant?" Jack wonders. His stepdaughter Denise tells her gum-chewing mother "That stuff causes cancer in laboratory animals in case you didn't know." At one point, the children's school is evacuated because of toxic fumes, which could be coming from

the ventilating system, the paint or varnish, the foam insulation, the electrical insulation, the cafeteria food, the rays emitted by microcomputers, the asbestos fireproofing, the adhesive on shipping containers, the fumes from the chlorinated pool, or perhaps something deeper, finer-grained, more closely woven into the basic state of things. [DeLillo 1984, p. 35]

In other words, everything is a potential hazard. And Heise argues that, just as DeLillo's characters cannot be sure what to believe, so in White Noise he creates a narrative structure in which the reader does not know what to believe either. (We will later see precisely the same device used by Thomas Pynchon.) Not just the half-familiar names of products - Mylex, Dylar, and so forth - but also the seemingly wilder comic inventions have an air of plausibility: Siskind's academic quest for a mythology of Elvis, college courses on the study of car-crash scenes in movies, drugs for suppressing irrational fears. Even the story in a supermarket tabloid that "From beyond the grave, dead living legend John Wayne will communicate telepathically with President Reagan to help frame U.S. foreign policy" starts to sound horribly possible. Thus, says Heise (2002), "the novel's narrative mode, which exacts decision making [about what is real and what is not] from the readers, mirrors in its form the fundamental uncertainties that beset risk assessments in the 'real world'."

It would be simplistic, then, to interpret White Noise as a warning about the dangers of chemical industry. It is, among other things, a mediation on the tragicomedy of our (which is to say, America's) simultaneous dependency on and ignorance of the products of that enterprise. The book ends with a description of people in a supermarket, thrown into agitation and panic when the shelves are rearranged without warning. "They walk in a fragmented trance", says Jack, "trying to figure out the pattern, discern the underlying logic, trying to remember where they'd seen the Cream of Wheat." 


\section{Corporate gain, public loss?}

In his 1998 novel Gain, Richard Powers presents a rather more somber analysis of this same dilemma. This is a fiction of almost unprecedented chemical sophistication. It tells two stories, shifting sequentially between them every few pages. One is concerned with the genesis of the fictional chemicals company Clare, which begins as a candle- and soap-making business run by two Irish immigrants in Boston in the nineteenth century and grows to share the stage with Lever, Colgate, and Procter and Gamble in manufacturing domestic products, foods, and agrochemicals. The other story is the tale of Laura Bodey, a real-estate agent living in modern-day Lacewood, Illinois - a town that owes its existence to the presence of Clare's factories and headquarters. Laura discovers she has ovarian cancer, which her ex-husband Don thinks was induced by proximity to the Clare chemical works.

Powers has a remarkable understanding of industrial history generally and of how the chemicals companies arose in particular. He quotes William Cullen, professor of chemistry at Glasgow and Edinburgh, who made one of the most eloquent defenses of chemistry as an applied science:

Chemistry is the art of separating mixt bodies into their constituent parts and of combining different bodies or the parts of bodies into new mixts [...] for the purposes of philosophy by explaining the composition of bodies [...] and for the purposes of arts by producing several artificial substances more suitable to the intention of various arts than any natural productions are. [Powers 2001, p. 35]

Cullen was in fact quite insistent on chemistry's role as handmaid to industry - in this same article he went on to say:

Does the mason want a cement? Does the dyer want a means of tinging a cloth of a particular colour? Or does the bleacher want the means of discharging all colours? It is the chemical philosopher who must supply these. [Cullen c.1766, quoted in Donovan 1975, p. 107.]

Powers points out how industry provided both the means and the motives for fundamental chemical research, in particular with the aim of finding out how to synthesize the molecules that were extracted at considerable cost and hazard from natural sources, and how they might be modified and improved:

Chemistry was not the means to soapmaking. Soapmaking was, rather, a means toward the consummate chemical end. To that goal, the elements moved from one incarnation to the other the way that the seasons, variously advantageous, moved through the eternally renewing year. If Nature were no more than eternal transformation, Man's meet and right pursuit consisted of emulating her. [Powers 2001, p. 79] 
And just as, in The Monkey's Wrench, Primo Levi exploited the fact that he was writing a novel rather than a textbook to show us a molecular diagram that no popular science writer would dare place before the reader, so Powers can risk displaying the most extraordinary chemical detail in describing the activities of the Clare company. He gives us in all its stoichiometric glory the Leblanc process for making soda from salt:

$$
\begin{aligned}
& 2 \mathrm{NaCl}+\mathrm{H}_{2} \mathrm{SO}_{4}=\mathrm{Na}_{2} \mathrm{SO}_{4}+2 \mathrm{HCl} \\
& \mathrm{Na}_{2} \mathrm{SO}_{4}+2 \mathrm{C}=\mathrm{Na}_{2} \mathrm{~S}+2 \mathrm{CO}_{2} \\
& \mathrm{Na}_{2} \mathrm{~S}+\mathrm{CaCO}_{3}=\mathrm{CaS}+\mathrm{Na}_{2} \mathrm{CO}_{3}
\end{aligned}
$$

Or, as an illustration of how the company made economies and at the same time diversified by recycling by-products as raw materials, we are shown on page 171 a diagram of the various uses of Glauber's salt.

What, one might ask, is this textbook material doing in a novel? Well, novels can do that kind of thing. Readers will tolerate it today because learned asides have become part of the modern novelist's technique. In a novel, unlike a non-fiction book, you do not feel you have to understand this stuff; you merely absorb it as a signifier of authenticity. Powers reminds us of this with a suitably flowery, cod-Victorian explanation of his chemical equations:

The symbols traipsed across the page, as cryptic as the skittering beetle code in that story by Mr. Poe from the Philadelphia Dollar Weekly. The first equation was a cotillion, a quadrille of decoupling and recoupling. $\mathrm{Na}$ and $\mathrm{Cl}$ parted amicably, grabbing the split partners of $2 \mathrm{H}$ and $\mathrm{SO}_{4}$ to forge new squares while still balancing beautifully across the equal sign. The second spun a sprightly Roger de Coverley, the terpsichorean set-and-a-half breaking down longways in the winding hey, $\mathrm{SO}_{4}$ cracking into two new dancers of its own right, with never a leg being gained or lost. [Powers 2001, p. 131]

The bottom line of all the technical details is clear enough: "Man now spun worth from worthlessness, gold from dross." The dream, in other words, of the chemical philosophy.

So fluent does Powers become in this chemicalization of culture that he can even toss us a (rather good) chemical joke or two, as when Laura Bodey's daughter admits to having provoked a fight with another girl at her school: "She says", Laura tells Don, "that she asked the girl how many viscoses died to make her blouse."

But Laura Bodey is, seemingly, there to remind us of the consequences of it all. In the light of the book's title, it could appear to take the shape of a morality tale: the business begun by the upright, honorable Clare brothers becomes transformed over the years into a greedy multinational that ends up endangering the citizens unfortunate enough to live close to its toxic, car- 
cinogenic effluent, or who use its chemical products. Inevitably perhaps, if rather depressingly, Powers was accused by some reviewers of taking an antiindustrial stance in which he mounts "an assault on corporate America" (Caldwell 1998). As with White Noise, such crude readings tell us more about the preoccupations of the reader than about the novel.

Powers himself is much more careful to balance his equation. For a start, it is never clear in Gain whether Laura's ultimately terminal illness is really connected to Clare products at all. As Don presses Laura to sue, she insists that there is no reason to believe that her cancer has environmental causes. When Don tells her that she is part of a cluster centered on Lacewood, she points out that "ovarian cancer doesn't cluster". She is due nothing, she thinks. "No more than anyone else with a body. No more than anyone who will get sick, which is everyone." Don's insistence comes to look like a part of the culture of compensation, a symptom of the modern need to find someone to blame (and to sue) for our misfortune.

As Don explains the case for the prosecution, it is apparent that he has striven manfully to grasp the science behind the issue - he does not accept this potential danger with the barely comprehending fatalism of the Gladneys:

The theory is that certain ring-shaped molecules $[\ldots]$ ones with chlorine in them, get taken up into the tissues of women. The body turns them into something called xenoestogen. Very long-lasting. These fake estrogens somehow trick the body, signal the reproductive system to start massive cell division $[\ldots]$ The thing is, these ring-chlorine things are found in certain pesticides. [Powers 2001, p. 319]

But the truth of the matter never becomes clear. Expert witnesses contradict one another's claims. Clare buys in some of its fertilizer feedstock from another firm, causing confusion about liability. Laura dies, but there is never any Hollywood-style payoff whereby the chemicals company is revealed to be the Machiavellian villain.

And even more pertinently, Laura realizes that establishing some kind of culpability with Clare would make no difference anyway. For this is how she and her fellow citizens have chosen to live. They use Clare's chemical products because they genuinely make life easier. More synthetic, perhaps, more manufactured - but easier. The famous DuPont slogan - Better Living Through Chemistry - is shown to live up to its promise. When Powers mimics DuPont by quoting from advertisements from the Industrial Processes Group of Clare Material Solutions, he is not indulging in some heavy-handed irony: 


\section{Life After Chemistry}

No, there's nothing wrong with this picture. There's nothing wrong with your magazine or printers either. We just thought you'd like to see what life would look like without those life-threatening chemical processes you read so much about these days [...] Life without chemistry would look a lot like no life at all.

Less knowledge is not the answer. Better knowledge is. Chemical processes are not the problem. They're the rules of the game.

It's elementary: your life is chemistry. [Powers 2001, p. 153]

And whatever the cause of Laura's cancer, chemistry is a big part of the attempted cure. She is given taxol, manufactured by Bristol-Myers Squibb "but Clare sells them cheap materials", her doctor tells her. "I thought the stuff was made with tree bark", Laura says. The doctor replies,

It used to be. Now they use artificial tree bark. Used to take six mature hundred-year-old Pacific yew trees to treat you. Pretty expensive, when you figure yew trees can only be harvested by clear-cutting [...] that's exactly where the science comes in. One of our home-team chemists has figured out how to make, in a test tube, what used to cost an arm and a leg and half a dozen yew trunks. The molecule that does all the good work is so complex that synthesizing an imitation was supposed to have taken years. But so many people were willing to pay so much for it that science has produced a substitute in record time [...] If you just get out of people's way, they'll figure out how to make what people need. [Powers 2001, p. 151f.]

Thus taxol becomes the analogue of DeLillo's Dylar, the "benign counterpart of the Nyodene D menace" as Jack Gladney puts it. More than this, even for Laura's son Tim comes to see that 'better chemistry' is the solution as well as the problem. He changes gradually from a college drop-out who stages annual hunger vigils in front of the Clare headquarters to a computer scientist at MIT who writes a program that predicts protein folding from sequence data. With that capability at their disposal,

people might create molecules to do anything. The team found itself staring at a universal chemical assembly plant at the level of the human cell. Together with a score of other machines just then coming into existence, their program promised to make anything the damaged cell called out for. [Powers 2001, p. $355]$.

And in the exhausted depths of her terminal illness, Laura herself sees that, even if Clare products did cause her condition, that is not ultimately where the problem lies. She is one of the millions who have willed companies like Clare into existence. These companies do no more and no less than make things, and this is what everyone wants them to do. "People want everything", she whispers. "That's their problem." Even when Don suggests that one of the products being scrutinized in the legal proceedings is a Clare herb- 
icide that she used on her garden, she sees that the dispute has no real meaning.

It makes no difference whether this business gave her cancer. They have given her everything else. Taken her life and molded it in every way imaginable, plus six degrees beyond imagining. Changed her life so greatly that not even cancer can change it more than halfway back. [Powers 2001, p. 320]

Is Powers promoting anti-capitalist dissent, or fatalism? It seems more likely that he is advocating no simple polarities; rather, Heise (2002) argues that his position is informed by modern commentaries on risk that present it as an inseparable component of the techno-economic system. According to sociologist Ulrich Beck (1992), "in advanced modernity, the social production of wealth is systematically associated with the social production of risks". Not only are such risks inevitable and pervasive, but they are uncertain and unpredictable even to specialists. Heise cites the work of historian of technology Thomas Hughes (1989), who, she says, argues that "these large-scale systems into which technologies are embedded have become so complex that they can no longer be easily understood or controlled, and therefore they give rise to risks whose origins and outcomes are extremely difficult to trace and to manage" (Heise 2002). While DeLillo explores the unnerving effects of such a cultural environment on its hapless inhabitants, Powers confronts more directly the question of who is to blame for it. His conclusion appears to be that blame becomes itself an outdated and meaningless notion. The industrialized world has its own ecology, its own food chains through which materials and energy are processed (as Powers illustrates with a dissection of the components of a disposable camera and their provenance), its own inevitable dangers and lines of defense. This ecosystem is self-sustaining: even Tim Bodey's protein-drug technology becomes, at the very end of the book, the foundation for a new corporation, a future pharmaceuticals company. 'Plastic' stands proxy for all our technologies when Powers says that "Plastic happens; that is all we need to know on earth" (Powers 1998, p. 771).

Does this mean that corporations and chemicals companies are not responsible for the ailments that their products and by-products may induce that we are all somehow 'responsible' for them? Powers avoids that kind of evasive, anodyne conclusion. For one thing, we cannot but feel the injustice of Laura Bodey's fate. Moreover, corporate malpractice in chemical companies unquestionably does occur, as the thalidomide and Bhopal incidents reveal; and the public-relations blandishments of Clare, regardless of whether or not the reader thinks their products have caused Laura's cancer, are all too reminiscent of the responses to such cases. But Gain succeeds in showing how a simplistic 'little guy against big business' narrative does us no favors either. And most of all, it illustrates the error and indeed the danger of imag- 
ining that the hazards of chemical manufacturing somehow stem from an intrinsic malignity within chemistry itself.

\section{Portentous polymers}

If Richard Powers seems to have done his homework, that is because he started it early. He says that as a child he always felt "destined to be a scientist", and he read Darwin's Voyage of the Beagle in fourth grade. He began studying at the University of Illinois as a physics major, but then switched to literature. He worked as a computer programmer after graduating, and continued to read about science. His other novels have also explored scientific themes: Prisoner's Dilemma (1988), as the title suggests, took in the game theory of nuclear conflict, while his most well-known work, The Gold Bug Variations (1991) used metaphors from genetics and computer science.

A similar background of scientific training informs Gravity's Rainbow, the book that made Thomas Pynchon a cult figure. Pynchon is famously reclusive, to the extent that there are no publicity photographs of him and the few facts that are known about his life have been gleaned only through the detective work of his obsessively curious fans. He studied engineering physics at Cornell in the 1950s before serving in the navy. He then returned to Cornell to study English, during which time he was taught by Vladimir Nabokov. But like Powers, he returned to technical work before his writing career took off, and in the early 1960s he was employed as an 'engineering aide' at Boeing. He worked on Gravity's Rainbow for seven years, completing it in 1973. It is said (although we should always be cautious about the Pynchon legend) that the novel was unanimously selected for the 1974 Pulitzer prize, but was turned down by the advisory board, who considered it not only 'turgid' and 'overwritten' but also 'obscene'.

No doubt the same charges (and worse) were leveled at Rabelais in the sixteenth century, whose Gargantua and Pantagruel are again the obvious literary forebears of Pynchon's extraordinary, sprawling work. Peppered with songs, scatology, science, and mathematical formulae (it is the only book I have ever seen with an algebraic joke), Gravity's Rainbow is impossible to categorize or to summarize. It is a text of Joycean complexity which eschews the conventions of traditional narrative even to the extent of allowing the central character to fade from the stage many pages before the end. For the present purposes, we need to know only that the events the book describes take place towards and immediately after the end of the Second World War, and that they are concerned with the development of the rocket program that began with the German V2 flying bombs, the arcing trajectory of which is 
alluded to in the book's title. What emerges is that the tail end of the war begins to look less like a conflict of nations and more like a business enterprise orchestrated by a conglomerate of companies within which the German chemicals cartel IG Farben looms large.

As in White Noise, the reader is thrown off balance, uncertain what is 'real' and what is 'fantasy'. Whereas DeLillo used such a narrative mode to mirror the vague forebodings of risk and danger in the minds of his characters, Pynchon recreates in this way a sense of the paranoia felt by his protagonist Tyrone Slothrop - Pynchon's equivalent of Joseph Heller's Yossarian, the wise-cracking, sympathetic yet helpless everyman - who is thrown this way and that by forces beyond his control or understanding. "Pynchon gives the impression of a politico-economic process taking place which can only be glimpsed and which seems to baffle logic", according to literary theorist David Seed (1988).

IG Farben is (or at least seems to be) the prime mover in this grand, behind-the-scenes plot. It is, of course, the ideal choice for such a villain, for the cartel manufactured Zyklon B poison gas and ran the Buna-Werke concentration camp on the outskirts of Auschwitz, comparable to the rocketbuilding labor camp at Peenemünde that hosts one of Pynchon's set-pieces in Gravity's Rainbow. Seed says that Pynchon "concentrates on IG as a process, a steady relentless agglomeration of power through mergers, takeovers and contracts [...] IG becomes the model of the totalitarian state". It is, indeed, the prototype of the modern military-industrial complex; but one in which the tentacles of power are entwined with elements of the occult and chthonic.

This again could be interpreted as a kind of ecological 'rage against the machine', and indeed the critic J.D. Black has, in Seed's words, “located Pynchon in a tradition of anti-technological dissent which presents man as the destroyer of a vitalistic earth" (Seed 1988). According to Black (1980), Pynchon "describes a Nature which has been ruthlessly violated, quantified, and technologically transformed by the irreversible, exhaustive process of history."

But again this seems simplistic. It is true that Pynchon expresses a profound distaste for the military-industrial complex: he has said that,

As well-known President and unintentional Luddite D.D. Eisenhower prophesied when he left office, there is now a permanent power establishment of admirals, generals and corporate CEO's, up against whom us average poor bastards are completely outclassed, although Ike didn't put it quite that way. We are all supposed to keep tranquil and allow it to go on, even though, because of the data revolution, it becomes every day less possible to fool any of the people any of the time. [Pynchon 1984] 
But that is a complaint about power structures, not technology per se. And in Gravity's Rainbow Pynchon is more interested in exploring the genealogy of this structure than in formulating an anti-technological stance.

A mysterious but central role in the nascent rocket technology is played by an ominous polymer called Imipolex G, which was developed in 1939 for IG Farben by Professor Laszlo Jamf. Jamf was taught by a pupil of August Wilhelm Hofmann, the German chemist whose student William Perkin triggered IG Farben's original line of business in dye manufacture with his discovery of the mauve coal-tar dye in 1856. (It is hinted darkly that there is some deep symbolic significance in that 'unfolding' of a new color from the molecules of long-dead organisms in coal-tar.) Jamf is Pynchon's Faust figure, whom he explicitly links in the novel to the character of Rothwang in Fritz Lang's Metropolis, and to Lang's diabolical Dr Mabuse, a psychologist who seeks world domination. Like the archetypically mad scientist, Jamf wants to cross forbidden boundaries, to blur the distinction between the living and the lifeless. And characteristically, Pynchon's chemistry borders on the sinisterly plausible:

'Silicon, boron, phosphorus [says Jamf] - these can replace carbon, and can bond to nitrogen instead of hydrogen [...] move beyond life, towards the inorganic. Here there is no frailty, no mortality - here is Strength, and the Timeless.' Then in his well-known finale, as he wiped away the scrawled $\mathrm{C}-\mathrm{H}$ on his chalkboard and wrote, in enormous letters, Si-N. [Pynchon 1995, p. 580]

Which of course spells out also: sin.

In tracing the origins of Imipolex G, Pynchon takes us deep into the early history of polymer science. The material is, he says,

traceable back to early research done at du Pont. Plasticity has its grand tradition and main stream, which happens to flow by way of du Pont and their famous employee Carothers, known as the Great Synthesist. His classic study of large molecules spanned the decade of the twenties and brought us directly to nylon, which not only is a delight to the fetishist and a convenience to the armed insurgent, but was also, at the time and well within the System, an announcement of Plasticity's central canon: that chemists were no longer to be at the mercy of Nature. They could decide now what properties they wanted a molecule to have, and then go ahead and build it. At du Pont, the next step after nylon was to introduce aromatic rings into the polyamide chain. Pretty soon a whole family of 'aromatic polymers' had arisen: aromatic polyamides, polycarbonates, polyethers, polysulfanes. [Pynchon 1995, p. 249f.]

Notice again this listing of names that will mean nothing to the average reader: a list that serves to say 'You might not have a clue what these things are, but someone else does, and that's why they have more power than you do.' And to rub this point in, Pynchon describes Jamf's chemical accomplish- 
ments in terms technical enough to suggest that again there is an intellect behind all of this that far exceeds the poor reader's:

Jamf, among others, then proposed, logically, dialectically, taking the parental polyamide sections of the new chain, and looping them around into rings too, giant 'heterocyclic' rings, to alternate with the aromatic rings. This principle was easily extended to other precursor molecules. A desired monomer of high molecular weight could be synthesized to order, bent into its heterocyclic ring, clasped, and strung in a chain along with the more 'natural' benzene or aromatic rings. Such chains would be known as 'aromatic heterocyclic polymers.' One hypothetical chain that Jamf came up with, just before the war, was later modified into Imipolex G. [Pynchon 1995, p. 250]

One might imagine that Pynchon could have got away with making this stuff up; but I am not sure that he could have made it sound authentic unless it really was (as, in essence, it is).

What is so special about Imipolex G? True to the nature of the narrative, Pynchon succeeds brilliantly in uniting the scientifically plausible, indeed even the prescient, with the wickedly sensual:

Imipolex $G$ is the first plastic that is actually erectile. Under suitable stimuli, the chains grow cross-links, which stiffen the molecule and increase intermolecular attraction so that this Peculiar Polymer runs far outside the known phase diagrams, from limp rubbery amorphous to amazing perfect tesselation, hardness, brilliant transparency, high resistance to temperature, weather, vacuum, shock of any kind [...] Evidently the stimulus would have had to be electronic. [Pynchon 1995, p. 699]

It was, in other words, what we would now call a smart material, the responsive skin of a deadly, almost sentient and all too phallic smart bomb.

For those not already familiar with Pynchon's style, these extracts, even though considerably edited, will perhaps serve to indicate the difficulty of summarizing what he means to say. His method is, in a Joycean manner, to work with allusion, to be constantly cross-referencing and hinting at broader themes. In Gravity's Rainbow, everything is part of a murky plan, everything refers to something else. Entire lexicons have been composed to help the reader navigate through the book's complex pathways.

But what must surely concern us here is that Pynchon has chosen to place the chemical industry at the core of his Great Scheme. His implication is that, if Knowledge is Power, then knowledge of how to synthesize things offers the greatest power of all. In a rather different idiom and certainly with a rather different setting than either DeLillo or Powers, Pynchon anticipates their conclusion that applied (that is, industrial) chemistry has more to tell us about the way modern life is structured than does any other applied science.

But it takes real understanding of the science to realize this, and to be able to express it in a literary context. Understanding; but also something more - 
something that I can only think of as a kind of materialist aesthetic, a delight in the smells and sights and textures and responsiveness of the substances and fabrics that make up our lives. This, I suspect, is a rather rare attribute today, and the conjunction of that with the skills needed to articulate it is rarer still. It is perhaps no surprise, then, that the writers I have discussed are exceptions in contemporary literature; and moreover they seem likely to remain so while chemistry continues to be seen as an unfashionable, even a moribund science. If that is a discouraging note on which to close, let us nevertheless note that these three texts offer a far richer basis than is typically found in today's mass media for discussing the impacts, origins, benefits, and dangers of technology in modern life. That debate is being prompted in particular by the emergence of biotechnology and nanotechnology, and fictional explorations of both these topics have tended to be predicated on lurid extrapolations into the future. In White Noise, Gain and Gravity's Rainbow we find instead perspectives on chemical technology that are clearly rooted in the past and the present; it is surely from here that any debate should begin.

\section{References}

Bacon, F.: 1620 (1944), Novum Organum, Wiley, New York.

Beck, U.: 1992, Risk Society: Towards a New Modernity, trans. M. Ritter, Sage, London.

Black, J.D.: 1980, 'Probing a post-Romantic palaeontology: Thomas Pynchon's Gravity's Rainbow', Boundary, 2, 8ii, p. 233.

Caldwell, G.: 1998, 'On the soapbox' (book review), Boston Sunday Globe, 7 June, C4.

Conroy, M.: 2003, 'From tombstone to tabloid: authority figured in White Noise', in: H. Bloom (ed.), Don DeLillo's White Noise, Chelsea House, Broomall, Philadelphia, p. 153.

Debus, A.G.: 1978, Man and Nature in the Renaissance, Cambridge UP, Cambridge.

DeLillo, D.: 1984, White Noise, Viking Penguin, New York.

Donovan, L.A.L.: 1975, Philosophical Chemistry in the Scottish Enlightenment, Edinburgh UP, Edinburgh.

Heise, U.K.: 2002, 'Toxins, drugs, and global systems: risk and narrative in the contemporary novel', American Literature, 74, no. 4.

Hughes, T.P.: 1989, American Genesis: A Century of Invention and Technological Enthusiasm, 1870-1970, Viking, New York.

LeClair, T.: 2003, 'Closing the loop: White Noise', in: H. Bloom (ed.), Don DeLillo's White Noise, Chelsea House, Broomall, Philadelphia, p. 5.

Lentricchia, F. (ed.): 1991, New Essays on White Noise, Cambridge UP, Cambridge.

Levi, P.: 1985, The Periodic Table, Abacus, London.

Levi, P: 1987, The Monkey's Wrench, Penguin, London.

Medawar, P.: 1984, 'Two conceptions of science', in: Pluto's Republic, Oxford University Press, Oxford, p. 35. 
Molesworth, C.: 1991, 'Don DeLillo's Perfect Starry Night', in: F. Lentricchia (ed.), Introducing Don DeLillo, Duke University Press, Durham, pp. 143-57.

Moses, M.V.: 1991, 'Lust removed from nature', F. Lentricchia (ed.), Introducing Don DeLillo, Duke UP, Durham, p. 63.

Multhauf, R. P.: 1993, The Origins of Chemistry, Gordon \& Breach, Langhorne, Pennsylvania.

Osteen, M.: 2000, American Magic and Dread, University of Pennsylvania Press, Philadelphia.

Powers, R.: 2001, Gain, Vintage, London.

Pynchon, T.: 1984, 'Is it O.K. to be a Luddite?', The New York Times Book Review, 28 October, pp. 40-1.

Pynchon, T.: 1995, Gravity's Rainbow, Penguin, London.

Rabelais, F.: 1532, 1534 (1955), Gargantua and Pantegruel, Penguin, Harmondsworth.

Schummer, J.: 2004, 'Why do chemists perform experiments?', in: D. Sobczynska, P. Zeidler \& E. Zielonacka-Lis (eds.), Chemistry in the Philosophical Melting Pot, Peter Lang, Frankfurt, pp. 395-410.

Seed, D.: 1988, The Fictional Labyrinths of Thomas Pynchon, Macmillan, Basingstoke.

Philip Ball:

Nature, 4-6 Crinan St., London N1 9XW, UK; p.ball@nature.com 